\title{
EFFECT OF ACTIVE DRY YEAST AND CHEMICAL FERTILIZATION ON VEGETATIVE GROWTH AND THE MAIN CONSTITUENTS OF EUONYMUS JAPONICUS THUNB. PLANT.
}

\author{
Safwat M. K. Abdel-Wahid; Naglaa Y. Labib and B.B. Rezk Alla. \\ Ornamental Plants Research Department, Hort. Res. Inst., \\ Agric. Res. Center, Giza, Egypt.
}

\begin{abstract}
This work was carried out in a plastic house during the two successive seasons of $2002 / 2003$ and $2003 / 2004$ at the nursery of Ornamental Plants Research Department, Horticulture Research Institute, Agricultural Research Center, Giza, Egypt, to study the influence of active dry yeast ( $4 \mathrm{~g} / \mathrm{l})$, two chemical fertilization levels ( 6 and $12 \mathrm{~g} / \mathrm{plant}$ ), alone or in combination, on vegetative growth and chemical constituents of Euonymus japonicus plant. The obtained results showed that using yeast twice plus $6 \mathrm{~g} \mathrm{NPK} /$ plant increased plant height, fresh and dry weights of shoots as well as nitrogen percentage in roots. Applying yeast twice alone led to an increment in number of branches, fresh and dry weights of roots, carotenoids content in leaves and potassium percentage in roots. While, supplying the plants with yeast thrice caused an increment in stem diameter, root length and nitrogen percentage in shoots. It can be concluded that using active dry yeast twice alone or with $6 \mathrm{~g} \mathrm{NPK/plant} \mathrm{enhanced} \mathrm{the} \mathrm{growth} \mathrm{of}$ Euonymus japonicus plants. From economical and environmental point of view, it can be recommended to use active dry yeast twice alone.
\end{abstract}

Key words: Active dry yeast, NPK fertilization, Euonymus.

\section{INTRODUCTION}

Euonymus japonicus Thunb. "Green Spire", Fam. Celastraceae is native to Japan. It is an evergreen, multistemmed shrub with a unique and strongly fastigiated growth habit. The leaves are extremely dark, glossy green or variegated. The shrub reaches $3-4.5 \mathrm{~m}$ high. Leaves opposite, simple, $2.5-7.5 \mathrm{~cm}$ long. Variegated types may revert back to green leaves - forms especially under excessive fertility. "Green Spire" is easily transplanted and adaptable to a variety of soil types, even clay or highly acidic soils. A good plant for dry areas; withstands salt spray, thrives in full sun to heavy shade (U.S. National Arboretum, 1999).

Using active dry yeast to improve plant growth was mentioned by some workers. It contains proteins, arginine, glycine, histidine, isolysine, leucine, lysine, methionine, cystine, phenylalanine, tyrosine, threonine, tryptophan and vitamin B (Anonymous, 1994). Meanwhile, Ahmed et al. (1997) used dry yeast on grapevine as foliar fertilizer and found that it enhanced growth and plants nutritional status. They attributed these beneficial effects to its content of protein, ash, glycogen, fats and cellulose. Ahmed (1998) on marjoram plants showed that spraying the plants with active dry yeast at $0.2 \%$ caused more branching, heavier herb and leaves dry weight.

Chemical fertilizers are an important source of plant nutrients, however, are expensive and, cause environmental pollution. Therefore, an attention was given to use the active dry yeast for its beneficial effects on plant growth.

Little work could be found in the literature concerning the effect of active dry yeast alone or in combination with NPK on ornamental plants; so the present work was carried out to investigate the effect of active dry yeast alone or with different rates of NPK on growth and chemical constituents of Euonymus japonicus Thunb. plant.

Fayoum J. Agric. Res. \& Dev., Vol.20, No.1, January, 2006 
This experiment was conducted in a plastic house at the ornamental nursery of Ornamental Plants Research Department, Horticulture Research Institute, Agricultural Research Center, Giza, Egypt, during the two successive seasons of 2002 / 2003 and 2003 / 2004 to investigate the effect of active dry yeast (Saccharomyces cerevisiae), two chemical fertilization levels and their combinations on vegetative growth and chemical constituents of Euonymus japonicus Thunb. plant. Homogenous seedlings (15 $-17 \mathrm{~cm}$ height having $1-2$ branches/plant) were planted on $16^{\text {th }}$ November in both seasons in plastic pots of $20 \mathrm{~cm}$ diameter filled with a mixture of clay and sand (1:1 $\mathrm{v} / \mathrm{v})$. Fertilizer treatments included two levels of commercial fertilizer (Kristal Nasr 20 $-20-20+$ T.E.). The trace elements (T.E.) were Zn (140 ppm), Fe (700 ppm), Mn $(420 \mathrm{ppm}), \mathrm{Cu}(160 \mathrm{ppm}), \mathrm{Mo}(140 \mathrm{ppm})$ and $\mathrm{B}(220 \mathrm{ppm})$. The used rates of fertilizers were $6 \mathrm{~g} /$ pot ( $3 \mathrm{~g} /$ pot twice, i.e. every 6 months) and $12 \mathrm{~g} / \mathrm{pot}(3 \mathrm{~g} / \mathrm{pot}$ four times, i.e. every 3 months). The application started one month after planting. In addition to control plants (without fertilization or yeast).

The active dry yeast was added once, twice and thrice every 4 months at the rate of $4 \mathrm{~g}$ dry yeast and $30 \mathrm{~g}$ sugar per liter. Each plant received $50 \mathrm{ml}$ of yeast solution as a soil drench. The application started one month after fertilization. Irrigation and agricultural practices were done whenever needed.

The experiment included two factors in a completely randomized design system. The main plot was active dry yeast and the sub - plot was fertilizer treatments. The experiment included 12 treatments with three replicates. Each replicate consisted of five plants, i.e. 15 plants in each treatment. The statistical analysis was carried out according to Snedecor and Cochran (1982). L.S.D. at 0.05 was used to compare the differences between treatments.

At the end of the experiment of each season the following data were recorded:

A - Vegetative growth:

1- Plant height $(\mathrm{cm})$.

2- Stem diameter $(\mathrm{mm})$ at $3 \mathrm{~cm}$ above pot surface.

3- Number of branches / plant.

4- Number of leaves / plant.

5- Fresh and dry weights of shoots $(\mathrm{g})$.

6- Main root length $(\mathrm{cm})$.

7- Fresh and dry weights of roots (g).

B - Main constituents:

1.Photosynthetic pigments ( $\mathrm{mg} / \mathrm{g}$ fresh leaves) was determined according to Saric et al. (1967).

2. Total carbohydrates percentage in shoots and roots were determined according to Herbert et al. (1971).

3.Nitrogen percentage in shoots and roots was determined using micro - Kjeldahl method [Pregl (1945) and Piper (1947)].

4.Phosphorus percentage in shoots and roots was determined according to Troug and Meyer (1939).

5.Potassium determination was carried out by using operation chart for Shimadzu Atomic Absorption Flame Spectrophotometer AA - 646 with a boiling air acetylene burner and recorded readout.

The mechanical and chemical analyses of experimental soil are presented in Tables A and B. These analyses were conducted before planting.

Fayoum J. Agric. Res. \& Dev., Vol.20, No.1, January, 2006 
Table (A): Mechanical analysis of the soil.

\begin{tabular}{|l|c|}
\hline Sand \% & 51.39 \\
\hline Silt \% & 31.63 \\
\hline Clay \% & 17.98 \\
\hline Soil texture & Sandy clay \\
\hline
\end{tabular}

Table (B): Chemical analysis of the soil.

\begin{tabular}{|c|c|c|c|c|c|c|c|}
\hline \multicolumn{2}{|c|}{ Cations Meq / L } & \multicolumn{2}{|c|}{ Anions Meq / L } & \multirow[b]{2}{*}{$\mathrm{pH}$} & \multirow[b]{2}{*}{8.60} & \multirow[b]{2}{*}{$\mathrm{N}$} & \multirow[b]{2}{*}{$480 \mathrm{ppm}$} \\
\hline $\mathrm{Na}^{+}$ & 1.00 & $\mathrm{HCO}_{3}^{-}$ & 1.30 & & & & \\
\hline $\mathrm{K}^{+}$ & 0.25 & $\mathrm{SO}_{4}^{-}$ & 0.30 & E.C. & $1.20 \mathrm{mmohs}$ & $\mathrm{P}$ & $38.0 \mathrm{ppm}$ \\
\hline $\mathrm{Ca}^{++}$ & 10.00 & $\mathrm{Cl}^{-}$ & 0.45 & \multirow{2}{*}{$\begin{array}{l}\text { Organic } \\
\text { matter }\end{array}$} & \multirow{2}{*}{$0.23 \%$} & $\mathrm{~K}$ & $564.0 \mathrm{ppm}$ \\
\hline $\mathrm{Mg}^{++}$ & 8.02 & & & & & & \\
\hline
\end{tabular}

\section{RESULTS AND DISCUSSION \\ A- Vegetative growth:}

From the data shown in Tables $(1-7)$ it can be noticed that there were significant increments over control in most vegetative growth characteristics in both seasons. There was a gradual increase in plant height, number of branches, and number of leaves/plant as well as fresh and dry weights of roots due to increasing the dose of active dry yeast alone till twice, while, more application led to a decrease in these parameters. Concerning NPK treatments, most of vegetative growth parameters were increased gradually with increasing the rate of NPK fertilizer alone. There was insignificant decrease in number of branches / plant and root length with increasing the rate of NPK to $12 \mathrm{~g} /$ plant.

\section{1- Plant height:}

Data in Table (1) revealed that applying active dry yeast once led to a gradual increase in plant height. Meanwhile, increasing the yeast application caused a decrease in plant height. This decreasing effect increased as the rate of NPK reached $12 \mathrm{~g} \mathrm{NPK} /$ plant. Treating the plants with yeast twice plus NPK at $6 \mathrm{~g} /$ plant resulted in the tallest plants in both seasons (42.83 and $42.00 \mathrm{~cm}$, respectively), however, the shortest ones were control plants ( 34.50 and $32.50 \mathrm{~cm}$, respectively).

\section{2-Stem diameter:}

Data presented in Table (1) indicated that there was a gradual increase in stem diameter as a result of increasing yeast application without NPK application. The increment of NPK alone led to a decrease in stem diameter. Increasing the yeast application to twice with $6 \mathrm{~g}$ NPK/plant caused a gradual increase in stem diameter; however, increasing the rate of NPK resulted in a gradual decrease in stem diameter with increasing yeast dose. The thickest stems in the two seasons $(6.50$ and $6.67 \mathrm{~mm}$, respectively) were those of the plants supplied with yeast three times without NPK fertilizer. The thinnest stems ( 5.33 and $5.43 \mathrm{~mm}$, respectively) were obtained from the plants treated with yeast three times and NPK at $12 \mathrm{~g} /$ plant in both seasons.

\section{3- Number of branches / plant:}

From the data in Table (2) it may be observed that in both seasons, same as in plant height, application of yeast once resulted in a gradual increase in number of branches/plant in combination with increasing NPK levels. However, there was a gradual decrease in number of branches as a result of increasing NPK rate and yeast amount. The greatest number of branches/plant was obtained by treating the plants with yeast twice without NPK fertilizer in the two seasons (6.33 and 6.50 branches/plant, respectively). While, the least number of branches/plant were found on control plants in the two seasons (2.33 and 2.83 branches/plant, respectively).

Fayoum J. Agric. Res. \& Dev., Vol.20, No.1, January, 2006 
4- Number of leaves / plant:

As shown in Table (2) the data pointed out that in the meantime yeast application combined with $6 \mathrm{~g} \mathrm{NPK} /$ plant led to a gradual increase in number of leaves/ plant in both seasons. Supplying the plants with yeast twice and NPK at the rate of $12 \mathrm{~g} /$ plant resulted in the greatest number of leaves/plant in the two seasons (124.33 and 129.00 leaves/plant, respectively), while, control plants had the least number of leaves/plant (57.67 and 71.00 leaves/plant, respectively).

Table (1): Effect of active dry yeast and chemical fertilization on plant height (cm) and stem diameter ( $\mathrm{mm}$ ) of Euonymus japonicus Thunb. during the two successive seasons of 2002 / 2003 and 2003 / 2004.

\begin{tabular}{|c|c|c|c|c|c|c|c|c|c|c|}
\hline \multirow{3}{*}{ yeast } & \multicolumn{6}{|c|}{ Plant height (cm) } & \multicolumn{4}{|c|}{ Stem diameter $(\mathrm{mm})$} \\
\hline & \multicolumn{10}{|c|}{ First season } \\
\hline & 0 & Once & Twice & Thrice & Mean & 0 & Once & Twice & Thrice & Mean \\
\hline 0 & 34.50 & 38.00 & 41.90 & 40.50 & 38.73 & 5.57 & 6.00 & 6.07 & 6.50 & 6.03 \\
\hline $6 \mathrm{~g}$ & 38.17 & 38.33 & 42.83 & 41.57 & 40.23 & 6.17 & 6.20 & 6.33 & 5.67 & 6.09 \\
\hline $12 \mathrm{~g}$ & 38.83 & 41.00 & 40.50 & 39.67 & 40.00 & 5.83 & 5.67 & 5.67 & 5.33 & 5.63 \\
\hline Mean & 37.17 & 39.11 & 41.74 & 40.58 & & 5.86 & 5.96 & 6.02 & 5.83 & \\
\hline $\begin{array}{c}\text { LSD at } \\
0.05\end{array}$ & \multicolumn{5}{|c|}{$\begin{array}{ll}\mathrm{A} \text { (yeast) } & =2.44 \\
\mathrm{~B}(\mathrm{NPK}) & =2.11 \\
\mathrm{~A} \times \mathrm{B} & =4.22\end{array}$} & \multicolumn{5}{|c|}{$\begin{array}{l}\mathrm{A}=0.56 \\
\mathrm{~B}=0.49 \\
\mathrm{~A} \times \mathrm{B}=0.98\end{array}$} \\
\hline \multicolumn{11}{|c|}{ Second season } \\
\hline 0 & 32.50 & 33.00 & 41.83 & 40.33 & 36.92 & 5.67 & 6.00 & 6.10 & 6.67 & 6.11 \\
\hline $6 \mathrm{~g}$ & 37.67 & 38.00 & 42.00 & 41.50 & 39.79 & 5.83 & 6.17 & 6.53 & 6.33 & 6.22 \\
\hline $12 \mathrm{~g}$ & 38.00 & 41.83 & 36.05 & 36.00 & 38.08 & 5.50 & 5.67 & 5.83 & 5.43 & 5.81 \\
\hline Mean & 36.05 & 37.61 & 40.11 & 39.28 & & 5.67 & 5.94 & 6.16 & 6.14 & \\
\hline $\begin{array}{c}\text { LSD at } \\
0.05\end{array}$ & \multicolumn{5}{|c|}{$\begin{array}{ll}\mathrm{A}(\text { yeast }) & =2.12 \\
\mathrm{~B}(\mathrm{NPK}) & =1.84 \\
\mathrm{~A} \times \mathrm{B} & =3.67\end{array}$} & \multicolumn{5}{|c|}{$\begin{array}{l}\mathrm{A}=0.82 \\
\mathrm{~B}=0.71 \\
\mathrm{~A} \times \mathrm{B}=1.41\end{array}$} \\
\hline
\end{tabular}

Table (2): Effect of active dry yeast and chemical fertilization on number of branches and leaves / plant of Euonymus japonicus Thunb. during the two successive seasons of 2002 / 2003 and 2003 / 2004.

\begin{tabular}{|c|c|c|c|c|c|c|c|c|c|c|}
\hline \multirow{3}{*}{ NPK } & \multicolumn{6}{|c|}{ Number of branches / plant } & \multicolumn{4}{|c|}{ Number of leaves / plant } \\
\hline & \multicolumn{10}{|c|}{ First season } \\
\hline & 0 & Once & Twice & Thrice & Mean & 0 & Once & Twice & Thrice & Mean \\
\hline 0 & 2.33 & 3.67 & 6.33 & 4.67 & 4.25 & 57.67 & 60.17 & 117.67 & 84.33 & 79.96 \\
\hline $6 \mathrm{~g}$ & 3.75 & 4.83 & 4.67 & 4.42 & 4.42 & 62.33 & 98.00 & 104.50 & 109.67 & 93.63 \\
\hline $12 \mathrm{~g}$ & 3.50 & 4.86 & 4.33 & 4.33 & 4.26 & 88.17 & 78.67 & 124.33 & 82.00 & 93.29 \\
\hline Mean & 3.19 & 4.45 & 5.11 & 4.47 & & 69.39 & 78.94 & 115.50 & 92.00 & \\
\hline $\begin{array}{c}\text { LSD at } \\
0.05\end{array}$ & \multicolumn{5}{|c|}{$\begin{array}{ll}\mathrm{A} \text { (yeast) } & =0.91 \\
\mathrm{~B}(\mathrm{NPK}) & =0.79 \\
\mathrm{~A} \times \mathrm{B} & =1.58\end{array}$} & \multicolumn{5}{|c|}{$\begin{array}{cr}\mathrm{A} & =4.15 \\
\mathrm{~B} & =3.60 \\
\mathrm{~A} \times \mathrm{B} & =7.19\end{array}$} \\
\hline \multicolumn{11}{|c|}{ Second season } \\
\hline 0 & 2.83 & 3.67 & 6.50 & 4.00 & 4.25 & 71.00 & 99.00 & 108.33 & 78.67 & 89.25 \\
\hline $6 \mathrm{~g}$ & 3.67 & 4.00 & 4.00 & 3.86 & 3.88 & 74.33 & 88.33 & 89.67 & 102.00 & 88.58 \\
\hline $12 \mathrm{~g}$ & 3.33 & 4.11 & 3.50 & 3.83 & 3.69 & 89.67 & 75.00 & 129.00 & 81.17 & 93.71 \\
\hline Mean & 3.28 & 3.93 & 4.67 & 3.90 & & 78.33 & 87.44 & 109.00 & 87.28 & \\
\hline $\begin{array}{c}\text { LSD at } \\
0.05\end{array}$ & \multicolumn{5}{|c|}{$\begin{array}{l}\mathrm{A} \text { (yeast) }=0.75 \\
\mathrm{~B}(\mathrm{NPK})=0.65 \\
\mathrm{~A} \times \mathrm{B}=1.30\end{array}$} & \multicolumn{5}{|c|}{$\begin{array}{l}\mathrm{A}=4.38 \\
\mathrm{~B}=3.80 \\
\mathrm{~A} \times \mathrm{B}=7.59\end{array}$} \\
\hline
\end{tabular}




\section{5- Fresh and dry weights of shoots:}

The data in Table (3) pointed out that the heaviest fresh and dry shoots were due to application of yeast twice plus NPK at $6 \mathrm{~g} /$ plant in both seasons, same as in plant height. The values were 69.43 and $56.88 \mathrm{~g}$, respectively for fresh weight and 18.00 and $14.37 \mathrm{~g}$, respectively for dry weight. Control plants had the least fresh and dry weights of shoots in the two seasons. The values were 25.40 and $32.47 \mathrm{~g}$, respectively for fresh weight and 6.48 and $8.50 \mathrm{~g}$, respectively for dry weight. There was a gradual increase in fresh and dry weights of shoots as a result of increasing yeast application without NPK fertilizer; however, with NPK fertilizer there was a gradual increase with increasing yeast application till twice. Concerning NPK treatments, there was a gradual increase in fresh and dry weights of shoots with increasing NPK rates alone or with yeast once. Meanwhile, increasing NPK level with yeast three times as a soil drench led to a gradual decrease in fresh and dry weights of shoots.

\section{6- Root length:}

From Table (4) it can be noticed that, in both seasons, increasing yeast application alone led to a gradual increase in root length. However, the interaction between yeast and the two levels of NPK resulted in an increment in root length till twice. There was a gradual decrease in root length due to increasing the rate of NPK alone or with yeast once. The tallest roots $(30.67$ and $26.00 \mathrm{~cm}$, respectively) were formed on the plants received yeast thrice alone, same as in stem diameter. While, treating the plants with $12 \mathrm{~g} \mathrm{NPK} /$ plant alone or with yeast once caused the formation of the shortest roots $(14.00 \mathrm{~cm})$ in the first season, while, in the second one $12 \mathrm{~g} \mathrm{NPK} /$ plant alone resulted in the shortest roots $(11.83 \mathrm{~cm})$.

Table (3): Effect of active dry yeast and chemical fertilization on fresh and dry weights (g) of shoots of Euonymus japonicus Thunb. during the two successive seasons of 2002 / 2003 and 2003 / 2004.

\begin{tabular}{|c|c|c|c|c|c|c|c|c|c|c|}
\hline \multirow{3}{*}{ Neast } & \multicolumn{5}{|c|}{ Fresh weight $(\mathrm{g})$ of shoots } & \multicolumn{5}{|c|}{ Dry weight $(\mathrm{g})$ of shoots } \\
\hline & \multicolumn{10}{|c|}{ First season } \\
\hline & 0 & Once & Twice & Thrice & Mean & 0 & Once & Twice & Thrice & Mean \\
\hline 0 & 25.40 & 30.19 & 49.79 & 60.85 & 41.56 & 6.48 & 7.73 & 13.03 & 15.67 & 10.73 \\
\hline $6 \mathrm{~g}$ & 29.15 & 36.28 & 69.43 & 56.03 & 47.72 & 7.54 & 9.41 & 18.00 & 14.67 & 12.41 \\
\hline $12 \mathrm{~g}$ & 41.58 & 52.38 & 58.97 & 53.48 & 51.60 & 10.71 & 13.54 & 15.00 & 14.00 & 13.31 \\
\hline Mean & 32.04 & 39.62 & 59.39 & 56.78 & & 8.24 & 10.23 & 15.34 & 14.78 & \\
\hline $\begin{array}{c}\text { LSD at } \\
0.05\end{array}$ & \multicolumn{5}{|c|}{$\begin{array}{ll}\mathrm{A} \text { (yeast) } & =2.01 \\
\mathrm{~B}(\mathrm{NPK}) & =1.74 \\
\mathrm{~A} \times \mathrm{B} & =3.49\end{array}$} & \multicolumn{5}{|c|}{$\begin{array}{l}\mathrm{A}=1.79 \\
\mathrm{~B}=1.55 \\
\mathrm{~A} \times \mathrm{B}=3.11\end{array}$} \\
\hline \multicolumn{11}{|c|}{ Second season } \\
\hline 0 & 32.47 & 46.57 & 49.28 & 50.07 & 44.60 & 8.50 & 11.67 & 12.73 & 12.93 & 11.46 \\
\hline $6 \mathrm{~g}$ & 41.95 & 47.39 & 56.88 & 46.18 & 48.10 & 10.63 & 12.67 & 14.37 & 11.57 & 12.31 \\
\hline $12 \mathrm{~g}$ & 42.00 & 49.05 & 50.80 & 44.42 & 46.57 & 10.73 & 11.97 & 12.60 & 11.37 & 11.67 \\
\hline Mean & 38.81 & 47.67 & 52.32 & 46.89 & & 9.96 & 12.10 & 13.23 & 11.96 & \\
\hline $\begin{array}{c}\text { LSD at } \\
0.05\end{array}$ & \multicolumn{5}{|c|}{$\begin{array}{l}\mathrm{A} \text { (yeast) }=2.35 \\
\mathrm{~B}(\mathrm{NPK})=2.04 \\
\mathrm{~A} \times \mathrm{B}=4.07\end{array}$} & \multicolumn{5}{|c|}{$\begin{array}{l}\mathrm{A}=1.61 \\
\mathrm{~B}=1.40 \\
\mathrm{~A} \times \mathrm{B}=2.79\end{array}$} \\
\hline
\end{tabular}

Fayoum J. Agric. Res. \& Dev., Vol.20, No.1, January, 2006 
Safwat M. K. Abdel-Wahid; et al.

Table (4): Effect of active dry yeast and chemical fertilization on root length (cm) of Euonymus japonicus Thunb. during the two successive seasons of $2002 / 2003$ and $2003 / 2004$.

\begin{tabular}{|c|c|c|c|c|c|c|c|c|c|c|}
\hline \multirow{2}{*}{ yeast } & \multicolumn{4}{|c|}{ First season } & \multicolumn{5}{c|}{ Second season } \\
\cline { 2 - 11 } & 0 & Once & Twice & Thrice & Mean & 0 & Once & Twice & Thrice & Mean \\
\hline 0 & 14.17 & 15.00 & 22.50 & 30.67 & 20.58 & 18.17 & 18.33 & 19.17 & 26.00 & 20.42 \\
$6 \mathrm{~g}$ & 14.17 & 14.33 & 27.00 & 19.67 & 18.79 & 17.33 & 18.00 & 21.67 & 16.33 & 18.33 \\
$12 \mathrm{~g}$ & 14.00 & 14.00 & 25.33 & 19.67 & 18.25 & 11.83 & 15.17 & 20.50 & 16.00 & 15.88 \\
\hline Mean & 14.11 & 14.44 & 24.94 & 23.33 & & 15.78 & 17.17 & 20.44 & 19.44 & \\
\hline LSD at & A (yeast) $=2.65$ & \multicolumn{4}{|c|}{ A $=1.96$} \\
0.05 & B (NPK) $=2.30$ & B $=1.70$ \\
& A x B & $=4.60$ & A x B = 3.39 \\
\hline
\end{tabular}

\section{7- Fresh and dry weights of roots:}

As shown in Table (5) the data revealed that there was a gradual increase in fresh and dry weights of roots as a result of increasing yeast application alone or with NPK at $6 \mathrm{~g} /$ plant till twice. These results coincided with those obtained on plant height and number of branches/plant. As for NPK treatments, increasing the rate of NPK alone led to a gradual increment in fresh and dry weights of roots. Meanwhile, the interaction between yeast twice or thrice application and NPK resulted in a gradual decrease in fresh and dry weights of roots with increasing NPK rate. Treating the plants with yeast twice alone led to the heaviest fresh and dry weights of roots, same as in number of branches/plant. The values were 39.68 and $35.34 \mathrm{~g}$, respectively for fresh weight and 13.67 and $11.93 \mathrm{~g}$ for dry weight in the first and second seasons, respectively. Control plants had the least fresh and dry weights of roots in the two seasons. The values were 21.42 and $17.36 \mathrm{~g}$, respectively for fresh weight and 7.57 and $6.13 \mathrm{~g}$ for dry weight in the two seasons, respectively.

Table (5): Effect of active dry yeast and chemical fertilization on fresh and dry weights (g) of roots of Euonymus japonicus Thunb. during the two successive seasons of 2002 / 2003 and 2003 / 2004.

\begin{tabular}{|c|c|c|c|c|c|c|c|c|c|c|}
\hline \multirow{3}{*}{ NPK } & \multicolumn{5}{|c|}{ Fresh weight (g) of roots } & \multicolumn{5}{|c|}{ Dry weight $(\mathrm{g})$ of roots } \\
\hline & \multicolumn{10}{|c|}{ First season } \\
\hline & 0 & Once & Twice & Thrice & Mean & 0 & Once & Twice & Thrice & Mean \\
\hline 0 & 21.42 & 30.14 & 39.68 & 33.68 & 31.23 & 7.57 & 10.53 & 13.67 & 11.67 & 10.86 \\
\hline $6 \mathrm{~g}$ & 22.64 & 32.08 & 34.90 & 32.07 & 30.42 & 8.00 & 11.10 & 12.33 & 11.33 & 10.69 \\
\hline $12 \mathrm{~g}$ & 30.85 & 22.45 & 34.02 & 29.81 & 29.28 & 10.90 & 7.93 & 11.67 & 10.57 & 10.27 \\
\hline Mean & 24.97 & 28.23 & 36.20 & 31.86 & & 8.82 & 9.86 & 12.56 & 11.19 & \\
\hline $\begin{array}{c}\text { LSD at } \\
0.05\end{array}$ & \multicolumn{5}{|c|}{$\begin{array}{ll}\mathrm{A}(\text { yeast } & =1.56 \\
\mathrm{~B}(\mathrm{NPK}) & =1.35 \\
\mathrm{~A} \times \mathrm{B} & =2.70\end{array}$} & \multicolumn{5}{|c|}{$\begin{array}{l}\mathrm{A}=1.33 \\
\mathrm{~B}=1.15 \\
\mathrm{~A} \times \mathrm{B}=2.30\end{array}$} \\
\hline \multicolumn{11}{|c|}{ Second season } \\
\hline 0 & 17.36 & 25.71 & 35.34 & 26.84 & 26.31 & 6.13 & 8.97 & 11.93 & 9.37 & 9.10 \\
\hline $6 \mathrm{~g}$ & 17.88 & 33.54 & 33.77 & 23.30 & 27.12 & 6.20 & 11.50 & 8.60 & 8.23 & 8.63 \\
\hline $12 \mathrm{~g}$ & 27.93 & 23.77 & 24.81 & 23.21 & 24.93 & 9.63 & 8.40 & 8.77 & 8.20 & 8.75 \\
\hline Mean & 21.06 & 27.67 & 31.31 & 24.45 & & 7.32 & 9.62 & 9.77 & 8.60 & \\
\hline $\begin{array}{c}\text { LSD at } \\
0.05\end{array}$ & \multicolumn{5}{|c|}{$\begin{array}{l}\mathrm{A} \text { (yeast) }=1.34 \\
\mathrm{~B}(\mathrm{NPK})=1.16 \\
\mathrm{~A} \times \mathrm{B}\end{array}$} & \multicolumn{5}{|c|}{$\begin{array}{l}\mathrm{A}=1.25 \\
\mathrm{~B}=1.08 \\
\mathrm{~A} \times \mathrm{B}=2.17\end{array}$} \\
\hline
\end{tabular}

These results coincided with those obtained by Ahmed et al. (1998) on roselle, Ahmed (1998) on marjoram, Refaat and Balbaa (2001) and Naguib (2002) on lemongrass and Ahmed (2001) on Calendula officinals who found that yeast treatments

Fayoum J. Agric. Res. \& Dev., Vol.20, No.1, January, 2006 
EFFECT OF ACTIVE DRY YEAST AND CHEMICAL

gave higher values for all characters than those obtained from the untreated plants. The most pronounced increments were in plant height, number of branches, fresh and dry weights.

Effect of yeast in enhancing the growth of Euonymus japonicus plants could be attributed to its content of minerals particularly $\mathrm{N}, \mathrm{P}$ and $\mathrm{K}$ and certain natural hormones, beside high amount of four vitamins, especially B which plays an important role in improving growth (Subba Rao, 1984).

\section{B- Main constituents:}

\section{1- Photosynthetic pigments in fresh leaves $(\mathrm{mg} / \mathrm{g})$ :}

Data represented in Table (6) revealed that the greatest chlorophyll (a) content in both seasons (1.29 and $1.27 \mathrm{mg} / \mathrm{g}$ fresh weight, respectively) was detected in the plants treated with yeast once and NPK at $6 \mathrm{~g} / \mathrm{plant}$. The least chlorophyll (a) content ( 0.26 and $0.24 \mathrm{mg} / \mathrm{g}$ fresh weight, respectively) was formed as a result of supplying the plants with yeast thrice alone.

As for chlorophyll (b) content, in both seasons, there was a gradual increase with increasing yeast application combined with NPK at $12 \mathrm{~g} /$ plant. However, with $6 \mathrm{~g}$ NPK / plant, the increment occurred till twice applying of yeast, but more yeast caused a decrease in chlorophyll (b) content. Regarding NPK treatments, increasing the rate to $12 \mathrm{~g} /$ plant alone or with yeast once led to a decrease in chlorophyll (b) content. Meanwhile, there was a gradual increase in chlorophyll (b) content as a result of increasing NPK level with yeast twice. The plants treated with yeast twice combined with $6 \mathrm{~g} \mathrm{NPK}$ / plant had the greatest chlorophyll (b) content $(0.43$ and $0.48 \mathrm{mg} / \mathrm{g}$ fresh weight, respectively), same as plant height and fresh and dry weights of shoots. While, treating the plants with active dry yeast thrice produced the least chlorophyll (b) content ( 0.11 and $0.12 \mathrm{mg} / \mathrm{g}$ fresh weight in the two seasons, respectively).

Concerning total chlorophylls content, the greatest amount $(1.67 \mathrm{mg} / \mathrm{g}$ fresh weight) in the first season, was detected in the plants received yeast once combined with $6 \mathrm{~g} \mathrm{NPK} \mathrm{/} \mathrm{plant,} \mathrm{same} \mathrm{as} \mathrm{chlorophyll} \mathrm{(a)} \mathrm{content.} \mathrm{In} \mathrm{the} \mathrm{second} \mathrm{season,} \mathrm{the}$ greatest amount $(1.65 \mathrm{mg} / \mathrm{g}$ fresh weight) was recorded in the plants treated with yeast twice plus $6 \mathrm{~g}$ NPK/plant, as chlorophyll (b) content, followed by yeast once with NPK at $6 \mathrm{~g} / \mathrm{plant}(1.63 \mathrm{mg} / \mathrm{g}$ fresh weight) without significant differences between them. The least amounts of total chlorophylls, in both seasons $(0.37 \mathrm{mg} / \mathrm{g}$ fresh weight $)$ were found due to treating the plants with yeast three times alone, same as chlorophylls (a) and (b).

Regarding carotenoids content, applying yeast twice alone, in both seasons, led to the greatest content $(0.66$ and $0.78 \mathrm{mg} / \mathrm{g}$ fresh weight, respectively), while, more application of yeast resulted in the least amounts of carotenoids $(0.13$ and $0.10 \mathrm{mg} / \mathrm{g}$ fresh weight, respectively), same as chlorophylls (a), (b) and total chlorophylls.

\section{2- Carbohydrates percentage in shoots:}

The data on total carbohydrates content shown in Table (7) pointed out that, in the two seasons, there was a gradual increment in total carbohydrates content due to increasing NPK level alone or with yeast once or twice. The highest total carbohydrates (33.47 and $23.58 \%$, respectively) were accumulated in the plants treated with yeast thrice combined plus NPK at $6 \mathrm{~g} /$ plant. Meanwhile, yeast once alone resulted in the formation of the least content of total carbohydrates (22.06 and $19.12 \%$, respectively).

\section{3- Nitrogen percentage in shoots:}

The recorded data for nitrogen percentage in shoots of Euonymus japonicus plants (Table 7) revealed that, in both seasons, there was a significant increment over control due to all treatments. A gradual increase in $\mathrm{N} \%$ was noticed as a result of increasing yeast application alone or with $6 \mathrm{~g}$ NPK/plant. As for NPK effect, there was

Fayoum J. Agric. Res. \& Dev., Vol.20, No.1, January, 2006 
a gradual increase in $\mathrm{N} \%$ in the plants with increasing its level alone or with yeast once. While, more supply of yeast led to a decrease in N \% with increasing NPK rate. The highest accumulation of nitrogen (2.46 and $2.42 \%$, respectively) was detected in the plants treated with yeast thrice alone, same as stem diameter and root length.

\section{4- Phosphorus percentage in shoots:}

Phosphorus percentage as affected by active dry yeast and NPK fertilizer was presented in Table (7). In both seasons, increasing NPK level alone or with yeast once or twice led to a gradual decrease in $\mathrm{P} \%$, while, more application of yeast resulted in a gradual increase in P \% with increasing NPK rate. The highest level of NPK led to a gradual increase in $\mathrm{P} \%$ with increasing yeast dose. The greatest amount of $\mathrm{P}(0.31$ and $0.38 \%$, respectively) was determined in the plants received yeast once alone. However, the least values ( 0.20 and $0.18 \%$, respectively) were of those treated with NPK alone at $12 \mathrm{~g} /$ plant.

\section{5- Potassium percentage in shoots:}

Data shown in Table (7) indicated that in both seasons, most treatments led to a significant increase in potassium percentage over control plants. Fertilizing the plants with NPK alone or with yeast once or twice caused a gradual increment in potassium percentage with increasing NPK rate.

Concerning the interaction between yeast and NPK, it can be observed that increasing NPK level from 6 to $12 \mathrm{~g} /$ plant resulted in an increment in potassium percentage with all yeast treatments. Also, there was a gradual increase in $\mathrm{K} \%$ with increasing yeast application plus $12 \mathrm{~g} \mathrm{NPK} /$ plant. The greatest values of potassium in both seasons (1.29 and $1.32 \%$, respectively) were determined in the plants treated with yeast three times plus NPK at $12 \mathrm{~g} /$ plant. While, the least percentages $(0.66$ and 1.02 $\%$, respectively) were found in the plants received yeast three times in combination with NPK at $6 \mathrm{~g} /$ plant.

\section{6- Carbohydrates percentage in roots:}

The data in Table (8) revealed that, in the two seasons, all treatments resulted in more accumulation of total carbohydrates in roots than in control plants. The highest values of total carbohydrates ( 20.88 and $14.09 \%$, respectively) were recorded in plants due to the interaction between yeast twice and NPK at $6 \mathrm{~g} /$ plant. Treating the plants with yeast once led to a gradual increase with increasing NPK level. While, yeast thrice resulted in a gradual decrease in total carbohydrates percentage with increasing NPK rate.

\section{7- Nitrogen percentage in roots:}

From the data in Table (8) it can be observed that the highest $\mathrm{N} \%$, in both seasons (2.74 and $2.29 \%$, respectively) were determined in plants which received yeast twice combined with NPK at $6 \mathrm{~g} /$ plant, same as in total carbohydrates percentage. The least values ( 0.85 and $1.21 \%$, respectively) were detected in plants treated with yeast once plus NPK at $12 \mathrm{~g} /$ plant. There was a gradual increase in N \% due to increasing NPK level alone or with yeast thrice, while, the interaction between yeast once and NPK led to a gradual decrease with increasing NPK level.

\section{8- Phosphorus percentage in roots:}

The data presented in Table (8) indicated that increasing yeast application till twice alone or with $6 \mathrm{~g} \mathrm{NPK} /$ plant resulted in a gradual increase in P \% in both seasons. Also, there was a gradual increase in accumulation of $\mathrm{P}$ in the roots as a result of increasing NPK rate alone or with yeast once. In the first season, treating the plants with yeast once combined with NPK at $12 \mathrm{~g} /$ plant led to the greatest amount of P $(0.38 \%)$ in roots. In the second season, supplying the plants with yeast once plus 12 
EFFECT OF ACTIVE DRY YEAST AND CHEMICAL................ 144

Tables 6,7

Fayoum J. Agric. Res. \& Dev., Vol.20, No.1, January, 2006 
Safwat M. K. Abdel-Wahid; et al.

Tables 8

Fayoum J. Agric. Res. \& Dev., Vol.20, No.1, January, 2006 
$\mathrm{g} /$ plant NPK or twice with $6 \mathrm{~g} \mathrm{NPK/plant} \mathrm{resulted} \mathrm{in} \mathrm{the} \mathrm{highest} \mathrm{content} \mathrm{of} \mathrm{P}(0.36 \%)$. In the two seasons, the plants which received yeast thrice with NPK at $12 \mathrm{~g} / \mathrm{plant}$ had the least percentage of phosphorus ( 0.19 and $0.18 \%$, respectively).

\section{9- Potassium percentage in roots:}

From the data in Table (8) it may be noticed that increasing NPK alone or with all applications of yeast, in both seasons, led to a gradual decrease in potassium percentage. Meanwhile, increasing yeast dose alone to twice caused a gradual increase in potassium percentage. Supplying yeast alone twice, in both seasons, resulted in the greatest values of potassium ( 0.96 and $1.21 \%$, respectively) but when combined with NPK at $12 \mathrm{~g} /$ plant led to the least K\% (0.53 and $0.59 \%$, respectively) even less than the control plants.

These results are in agreement with those obtained by other workers such as Ahmed (2001) on Calendula officinals, Youssef and Moussa (2001) on Mentha piperita, Refaat and Balbaa (2001) and Naguib (2002) on lemongrass, who found that active dry yeast treatments led to the highest $\mathrm{N}, \mathrm{P}$ and $\mathrm{K}$ content. These increments might be due to the enhancement effect of yeast on some metabolic activities in the plants which leads to good accumulation of nutrients (Fruton and Simmonds, 1959).

\section{REFERENCES}

Ahmed, E.T. (1998). Influence of concentration and time of spraying active dry yeast on growth and volatile oil content of marjoram plants. J. Agric. Sci., Mansoura Univ., 23 (11): 5067 - 5081.

Ahmed, F.A. (2001). Response of marigold (Calendula officinalis L.) plants to some rock phosphate sources and yeast. Proc.Fifth Arab. Hort. Conf., Ismailia, Egypt, pp. $31-41$.

Ahmed, F.F.; A.M. Akl; F.M. El-Morsy and M.A. Ragab (1997). The beneficial effects of biofertilizer on Red Roomy Grapevine (Vitis vinifera L.). The effect on berry set, yield and quality of berries. Annals Agric. Sci., Moshtohor, 45 (1): 497 - 502.

Ahmed, S.K.; E.O. El-Ghawas and A.F. Aly (1998). Effect of active dry yeast and organic manure on roselle plant. Egypt. J. Agric. Res., 76 (3): 1115 -1143 .

Anonymous (1994). Nutrient Requirements of Poultry, p. 68, Subcommittee on Poultry Nutrition, Committee on Animal Nutrition, Board on Agriculture, National Research Council. National Academy Press Washington, D.C.

Fruton, J.S. and S. Simmonds (1959). General Biochemistry. John Wiley \& Sons, Inc., New York. P: 333 - 336.

Herbert, D.; P.J. Philipps and R.E. Strange (1971). Determination of total carbohydrates. Methods in Microbiol., 58: 209 - 344.

Naguib, Nabila Y. (2002). Yield and quality of lemongrass plants (Cymbopogon flexuous Stapf.) as influenced by farmyard manure and foliar application of bread yeast. Annals of Agric. Sci., Cairo, 47 (3): $859-873$.

Piper, C.S. (1947). Soil and Plant Analysis. P: 258 - 275. Univ. of Adelaide, Adelaide, Australia.

Pregl, F. (1945). Quantitative Organic Microanalysis 4th ed. Church. Lond.

Refaat, A.M. and L.A. Balbaa (2001). Yield and quality of lemongrass plants (Cymbopogon flexuous Stapf.) in relation to foliar application of some vitamins and microelements. Egypt. J. Hort., 28 (1): $41-57$.

Fayoum J. Agric. Res. \& Dev., Vol.20, No.1, January, 2006 
Safwat M. K. Abdel-Wahid; et al.

Saric, M.; R. Kastrori; R. Curic; T. Cupina and I. Geric (1967). Chlorophyll Determination. Univerzit et U Noveon Sadu. Praktikum iz Fiziologize Bilijaka Beograd Haucna Anjiga. 215 pp.

Snedecor, G.W. and W.G.Cochran (1982). Statistical Methods. The Iowa State Univ., Press., Ames., Iowa, USA, 507 pp.

Subba Rao, N.S. (1984). Biofertilizers in Agriculture. Oxford IBH Company New Delhi. p. 189

Troug, E. and R.H. Meyer (1939). Improvement in deiness colorimetric methods for phosphorus and arsinic. Ind. Eng. Chem. Anal. Ed., (1): 136 $-139$.

U.S. National Arboretum (1999). "Green Spire" Japanese Euonymus. U.S. Department of Agriculture. Agriculture Research Service, 3501 New York Ave., N.E. Washington, D.C.

Youssef, A.A. and Z.A. Moussa (2001). Effect of foliar application of Biotin and Pix on the growth and chemical composition of Bulgarian peppermint produced under Egyptian local conditions. J. Agric. Sci. Mansoura Univ., Egypt, 26 (5): 3331 - 3340.

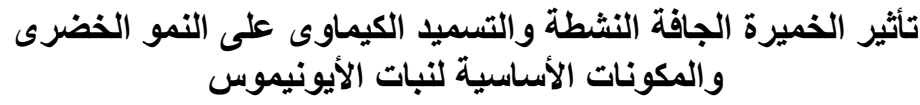

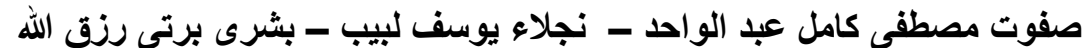

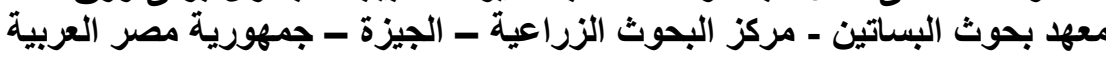

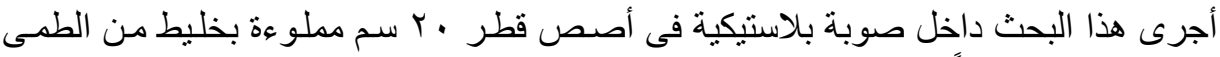

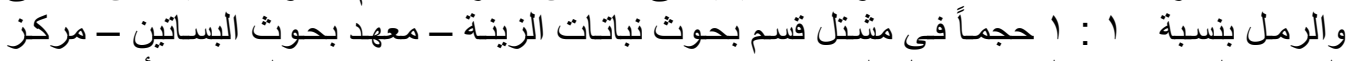

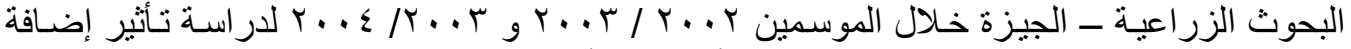

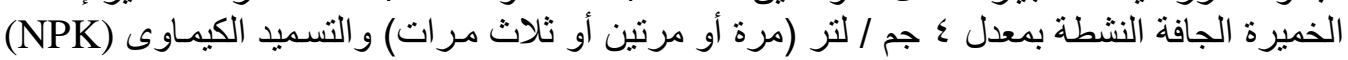

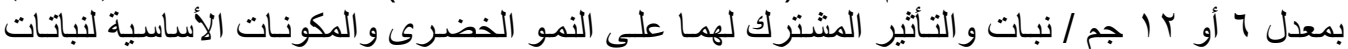

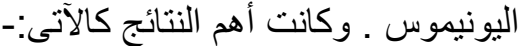

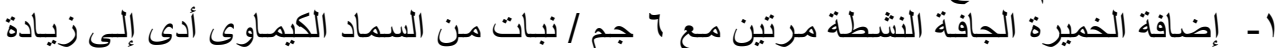

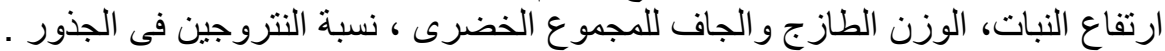

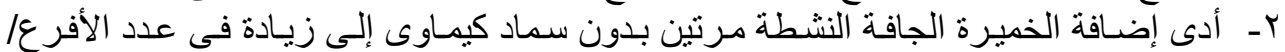

نبات، الوزن الطازج و الجاف للجذور ، الكاروتينويدات في الأوراق، كما أدى إلى زئى زيادة نسبة الإفية

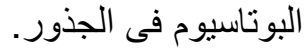

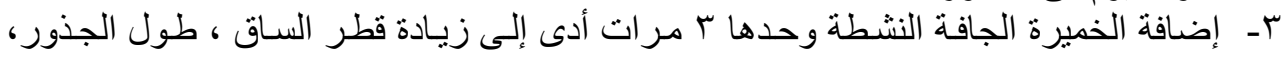

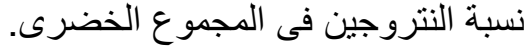

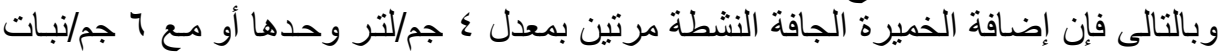

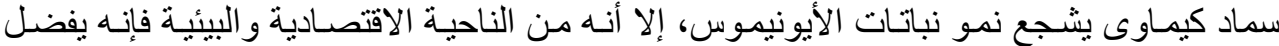

إضافة الخميرة الجافة النشطة مرتين وحدها وبدون تسميد كيماوى للحفاظ على البيئة من التلوثة التئ

Fayoum J. Agric. Res. \& Dev., Vol.20, No.1, January, 2006 